National and Global Petroleum Assessment

\title{
Assessment of Continuous Oil and Gas Resources in Jurassic Shales of the Eastern Arabian Peninsula, 2019
}

Using a geology-based assessment methodology, the U.S. Geological Survey estimated undiscovered, technically recoverable mean resources of 5.6 billion barrels of oil and 109.1 trillion cubic feet of gas in the Jurassic Hanifa-Tuwaiq Total Petroleum System of the Arabian Peninsula.

\section{Introduction}

The U.S. Geological Survey (USGS) quantitatively assessed the potential for undiscovered, technically recoverable continuous oil and gas resources in the Jurassic Hanifa-Tuwaiq Total Petroleum System (TPS) of the eastern Arabian Peninsula (fig. 1). Throughout much of the Mesozoic, the Arabian Peninsula formed the northeastern part of a broad north-facing passive margin of the neo-Tethys Ocean. Limited clastic input and the latitudinal position of the Arabian Plate led to the formation of extensive carbonate platforms and ramps, with a spectrum of carbonate platform, slope, and basinal sediments being deposited during much of the Mesozoic (Droste, 1990; Hughes, 2004). Associated with the shallow-water platforms were deeper basinal areas called intrashelf basins (Vahrenkamp and others, 2015; Al Ibrahim and others, 2017). Limited oceanic circulation in these intrashelf basins led to anoxic conditions and the deposition and preservation of organic matter in the transgressive systems tracts of the Tuwaiq Mountain and Hanifa Formations during the Callovian and Oxfordian Stages (Al Ibrahim and others, 2017). These organic-rich sediments form the primary source rocks for some of the largest oil fields in the world, including Ghawar (Pollastro, 2003). The two main intrashelf basinal areas evaluated in this study are the Central Arabian Subbasin and the South Arabian Gulf Subbasin (Pollastro, 2003; Al Ibrahim and others, 2017). The purpose of this study is to quantify the potential resources of continuous shale oil and shale gas retained within the shales of the Tuwaiq Mountain and Hanifa Formations in these two intrashelf basins.

\section{Total Petroleum System and Assessment Units}

The USGS defined the Jurassic Hanifa-Tuwaiq TPS and the Jurassic Tuwaiq-Hanifa Shale Oil Assessment Unit (AU) in the Central Arabian Subbasin and the Jurassic Tuwaiq-Hanifa Shale Gas AU in the South Arabian Gulf Subbasin. AU boundaries were defined using shale thickness greater than 15 meters, total organic carbon content greater than 2 weight percent, and mapped areas of thermal maturation for oil and gas. The boundaries of the intrashelf basins are well known (Pollastro, 2003; Vahrenkamp and others, 2015; Marchionda and others, 2017), and the boundaries were largely adopted to delineate the two AUs in this study. The thermal maturation data used to define the AUs were from Cantrell and others (2014). The areas of thermal maturity as mapped are most likely more complex than shown, and it is possible, for example, that within the Jurassic Hanifa-Tuwaiq Shale Oil AU, there are areas that have achieved the necessary thermal maturity for localized condensate or gas generation.

The Jurassic shales of the Tuwaiq Mountain and Hanifa Formations contain Type IIS and Type II kerogen, have total organic carbon (TOC) contents as much as 14 weight percent, and hydrogen indices as much as 800 milligrams of hydrocarbon per gram of TOC. Thickness of shale in the Tuwaiq Mountain Formation is as much as 130 meters, and the shale of the Hanifa Formation is as much as 85 meters (Pollastro, 2003; Cantrell and others, 2014; Al Ansari and others, 2016). These shales are considered unique in terms of the high percentage of carbonate and the lack of clays (Al Ansari and others, 2016; Bromhead and others, 2017).

The assessment input data are summarized in table 1.

\section{Geologic Model for Assessment}

The geologic model for the assessment is for oil to have begun initial generation in the Late Cretaceous from the source rocks of the Tuwaiq Mountain and Hanifa Formations. Some of the oil migrated updip into large conventional traps, and portions of the oil were retained within the shales of the Tuwaiq Mountain and Hanifa Formations. In areas of deeper burial such as the South Arabian Gulf Subbasin and possibly the eastern part of the Central Arabian Subbasin, the oil would have reached temperatures sufficient to crack to gas during the Tertiary.
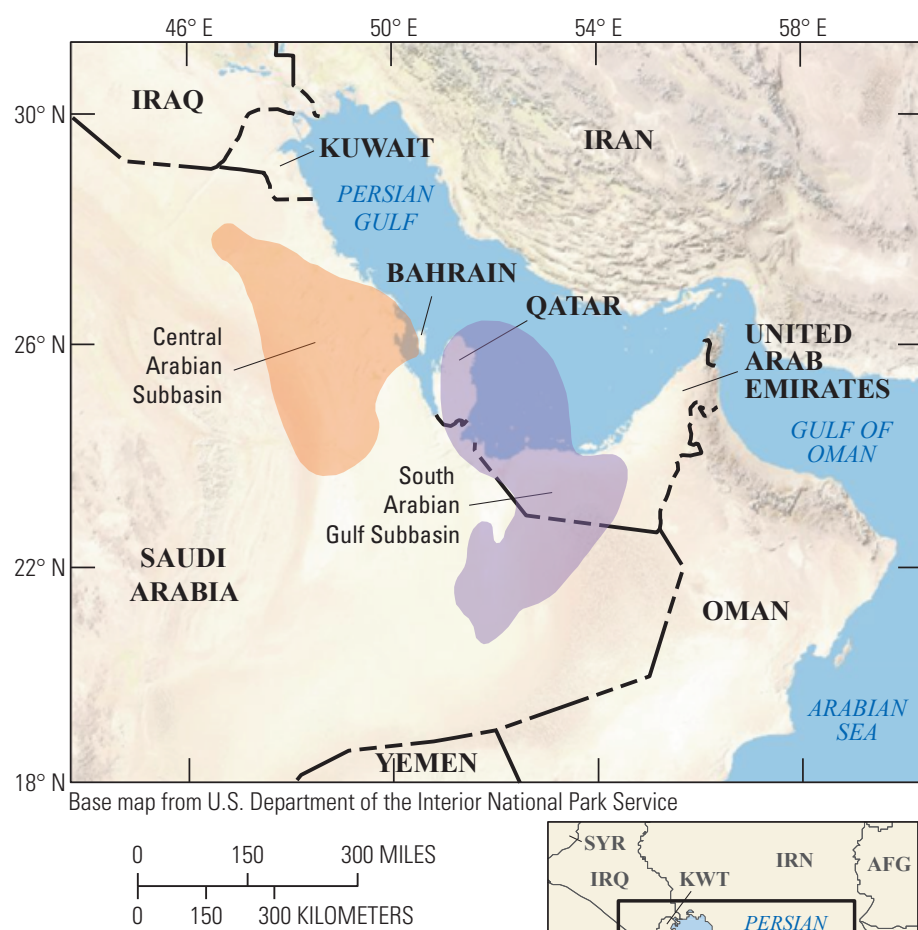

EXPLANATION

Jurassic Hanifa-Tuwaiq Shale Oil AU

Jurassic Hanifa-Tuwaiq Shale Gas AU

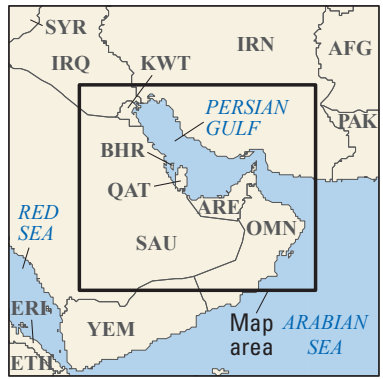

Figure 1. Map showing location of two continuous assessment units in the Jurassic Hanifa-Tuwaiq Total Petroleum System of the eastern Arabian Peninsula. 
Table 1. Key input data for two continuous assessment units in the Jurassic Hanifa-Tuwaiq Total Petroleum System of the eastern Arabian Peninsula.

[AU, assessment unit; \%, percent; EUR, estimated ultimate recovery per well; MMBO, million barrels of oil, BCFG, billion cubic feet of gas. The average EUR input is the minimum, median, maximum, and calculated mean. Shading indicates not applicable]

\begin{tabular}{|c|c|c|c|c|c|c|c|c|}
\hline \multirow{2}{*}{$\begin{array}{l}\text { Assessment input data- } \\
\text { Continuous AUs }\end{array}$} & \multicolumn{4}{|c|}{ Jurassic Hanifa-Tuwaiq Shale Oil AU } & \multicolumn{4}{|c|}{ Jurassic Hanifa-Tuwaiq Shale Gas AU } \\
\hline & Minimum & Mode & Maximum & $\begin{array}{l}\text { Calculated } \\
\text { mean }\end{array}$ & Minimum & Mode & Maximum & $\begin{array}{l}\text { Calculated } \\
\text { mean }\end{array}$ \\
\hline Potential production area of AU (acres) & 1,000 & $10,795,000$ & $21,590,000$ & $10,795,333$ & 1,000 & $15,859,500$ & $31,719,000$ & $15,859,833$ \\
\hline Average drainage area of wells (acres) & 80 & 120 & 160 & 120 & 80 & 120 & 160 & 120 \\
\hline Success ratio $(\%)$ & 10 & 50 & 90 & 50 & 10 & 50 & 90 & 50 \\
\hline Untested area in AU (\%) & 100 & 100 & 100 & 100 & 100 & 100 & 100 & 100 \\
\hline Average EUR (MMBO, oil; BCFG, gas) & 0.04 & 0.12 & 0.24 & 0.125 & 0.1 & 1.5 & 3 & 1.55 \\
\hline AU probability & 1.0 & & & & 1.0 & & & \\
\hline
\end{tabular}

\section{Undiscovered Resources Summary}

The USGS quantitatively assessed undiscovered, technically recoverable continuous oil and gas resources within the Jurassic Hanifa-Tuwaiq Total Petroleum System of the eastern Arabian Peninsula (table 2). The estimated mean totals for continuous resources are 5,639 million barrels of oil (MMBO), or 5.6 billion barrels of oil, with an F95-F5 range from 1,303 to 12,030 MMBO; 109,082 billion cubic feet of gas (BCFG), or 109.1 trillion cubic feet of gas, with an F95-F5 range from 24,945 to 236,043 BCFG; and 422 million barrels of natural gas liquids (MMBNGL) with an F95-F5 range from 82 to 998 MMBNGL.

Table 2. Results for two continuous assessment units in the Jurassic Hanifa-Tuwaiq Total Petroleum System of the eastern Arabian Peninsula.

[MMBO, million barrels of oil; BCFG, billion cubic feet of gas; NGL, natural gas liquids; MMBNGL, million barrels of natural gas liquids. Results shown are fully risked estimates. F95 represents a 95-percent chance of at least the amount tabulated; other fractiles are defined similarly. Fractiles are additive under the assumption of perfect positive correlation. Shading indicates not applicable]

\begin{tabular}{|c|c|c|c|c|c|c|c|c|c|c|c|c|c|c|}
\hline \multirow{3}{*}{$\begin{array}{l}\text { Total petroleum system and } \\
\text { assessment units (AUs) }\end{array}$} & \multirow{3}{*}{$\begin{array}{l}\text { AU } \\
\text { proba- } \\
\text { bility }\end{array}$} & \multirow{3}{*}{$\begin{array}{l}\text { Accu- } \\
\text { mulation } \\
\text { type }\end{array}$} & \multicolumn{12}{|c|}{ Total undiscovered resources } \\
\hline & & & \multicolumn{4}{|c|}{ Oil (MMBO) } & \multicolumn{4}{|c|}{ Gas (BCFG) } & \multicolumn{4}{|c|}{ NGL (MMBNGL) } \\
\hline & & & F95 & $\mathrm{F} 50$ & F5 & Mean & F95 & F50 & F5 & Mean & F95 & $\mathbf{F 5 0}$ & F5 & Mean \\
\hline \multicolumn{15}{|c|}{ Jurassic Hanifa-Tuwaiq Shale Total Petroleum System } \\
\hline Jurassic Hanifa-Tuwaiq Shale Oil AU & 1.0 & Oil & 1,303 & 5,051 & 12,030 & 5,639 & 1,451 & 5,861 & 15,180 & 6,773 & 16 & 69 & 190 & 81 \\
\hline Jurassic Hanifa-Tuwaiq Shale Gas AU & 1.0 & Gas & & & & & 23,494 & 90,859 & 220,863 & 102,309 & 66 & 285 & 808 & 341 \\
\hline Total undiscovered continuous resources & & & 1,303 & 5,051 & 12,030 & 5,639 & 24,945 & 96,720 & 236,043 & 109,082 & 82 & 354 & 998 & 422 \\
\hline
\end{tabular}

\section{References Cited}

Al Ansari, Y., Fateh, A., Shehab, A., Almoulani, G., Ghosh, A., Ahmed, A., and Thampi, S., 2016, Hanifa-Tuwaiq Mountain zone-The edge between conventional and unconventional systems: American Association of Petroleum Geologists, Search and Discovery Article No. 80539, 14 p., accessed June 24, 2019, at http:/www.searchanddiscovery.com/pdfz/documents/2016/ 80539alansari/ndx_alansari.pdf.html.

Al Ibrahim, M.A., Sarg, J.F., Hurley, N., Cantrell, D.L., and Humphrey, J.D., 2017, Depositional environments and sequence stratigraphy of carbonate mudrocks using conventional geologic observations, multiscale electrofacies visualization, and geochemical analysis - The case of the Tuwaiq Mountain and Hanifa Formations in a basinal setting, Saudi Arabia: The American Association of Petroleum Geologists Bulletin, v. 101, no. 5, p. 683-714.

Bromhead, A.D., Sutcliffe, O., Hay, D., and Evans, K., 2017, Lessons learned from the Vaca Muerta - An exploration model to aid sweet-spot prediction in the frontier Hanifa unconventional resource play in the Middle East, in Unconventional Resources Technology Conference (URTeC), Austin, Texas, July 24-26, 2017, Proceedings: Society of Exploration Geophysicists, American Association of Petroleum Geologists, Society of Petroleum Engineers, URTeC 2670610, 15 p., accessed June 24, 2019, at https://doi.org/10.15530/urtec-2017-2670610.

Cantrell, D.L., Nicholson, P.G., Hughes, G.W., Miller, M.A., Buhllar, A.G., Abdelbagi, S.T., and Norton, A.K., 2014, Tethyan petroleum systems of Saudi Arabia: American Association of Petroleum Geologists Memoir 106, p. 613-639.
Droste, H., 1990, Depositional cycles and source rock development in an epeiric intra-platform basin - The Hanifa Formation of the Arabian Peninsula: Sedimentary Geology, v. 69, nos. 3-4, p. 281-296.

Hughes, G.W.G., 2004, Middle to Upper Jurassic Saudi Arabia carbonate petroleum reservoirs - Biostratigraphy, micropaleontology and paleoenvironments: GeoArabia, v. 9, no. 3, p. 79-114.

Marchionda, E., Deschamps, R., Cobianchi, M., Nader, F.H., DiGiulio, A., Morad, D.J., Al Darmaki, F., and Ceriani, A., 2017, Field-scale depositional evolution of the Upper Jurassic Arab Formation (onshore Abu Dhabi, UAE [United Arab Emirates]): Marine and Petroleum Geology, v. 89, no. part 2, p. $350-369$

Pollastro, R.M., 2003, Total petroleum systems of the Paleozoic and Jurassic, Greater Ghawar Uplift and adjoining provinces of central Saudi Arabia and northern Arabian-Persian Gulf: U.S. Geological Survey Bulletin 2202-H, 100 p.

Vahrenkamp, V.C., Van Laer, P., Franco, B., Celetano, M.A., Grelaud, C., and Razin, P., 2015, Late Jurassic to Cretaceous source rock prone intrashelf basins of the eastern Arabian plate-Interplay between tectonism, global anoxic events and carbonate platform dynamics, in International Petroleum Technology Conference (IPTC), Doha, Qatar, December 6-9, 2015, Proceedings: IPTC, IPTC-18479-MS, accessed June 24, 2019, at https://doi.org/10.2523/IPTC-18470-MS.

\section{For More Information}

Assessment results are also available at the USGS Energy Resources Program website at https://energy.usgs.gov.

\section{Arabian Peninsula Assessment Team}

Christopher J. Schenk, Tracey J. Mercier, Cheryl A. Woodall, Marilyn E. Tennyson, Thomas M. Finn, Michael E. Brownfield, Kristen R. Marra, Phuong A. Le, Ronald M. Drake II, and Scott A. Kinney 